IZA DP No. 4771

Do Women Manage Smaller Funds?

Olaf Hübler

Lukas Menkhoff

February 2010 


\title{
Do Women Manage Smaller Funds?
}

\author{
Olaf Hübler \\ Leibniz Universität Hannover, \\ IAB Nürnberg and IZA \\ Lukas Menkhoff \\ Leibniz Universität Hannover
}
Discussion Paper No. 4771
February 2010

\author{
IZA \\ P.O. Box 7240 \\ 53072 Bonn \\ Germany \\ Phone: +49-228-3894-0 \\ Fax: +49-228-3894-180 \\ E-mail: iza@iza.org
}

Any opinions expressed here are those of the author(s) and not those of IZA. Research published in this series may include views on policy, but the institute itself takes no institutional policy positions.

The Institute for the Study of Labor (IZA) in Bonn is a local and virtual international research center and a place of communication between science, politics and business. IZA is an independent nonprofit organization supported by Deutsche Post Foundation. The center is associated with the University of Bonn and offers a stimulating research environment through its international network, workshops and conferences, data service, project support, research visits and doctoral program. IZA engages in (i) original and internationally competitive research in all fields of labor economics, (ii) development of policy concepts, and (iii) dissemination of research results and concepts to the interested public.

IZA Discussion Papers often represent preliminary work and are circulated to encourage discussion. Citation of such a paper should account for its provisional character. A revised version may be available directly from the author. 
IZA Discussion Paper No. 4771

February 2010

\section{ABSTRACT}

\section{Do Women Manage Smaller Funds?*}

Based on a sample of 467 asset managers from four countries we robustly find that women manage smaller funds than men, despite tough competition in this industry. Interestingly, the gender gap exists only for managers of smaller funds, i.e. at the lower end of the hierarchy, as quantile regressions show. This is inconsistent with the glass ceiling hypothesis. Going further, this gender gap is limited to large firms. Explanations may refer to large firms using market power in the area of smaller funds or to "visibility" among top asset managers protecting against unequal treatment of the sexes.

JEL Classification: J16, J44, G23

Keywords: asset managers, gender, qualification, segregation, attitudes

Corresponding author:

Olaf Hübler

Department of Economics

Leibniz Universität Hannover

Königsworther Platz 1

D-30167 Hannover

Germany

E-mail: huebler@ewifo.uni-hannover.de

\footnotetext{
* We very much appreciate the contributions made by the fund managers who were available for interviews and took time to respond to the survey. We thank the Investment Management Associations in Germany and Italy for the provision of supportive recommendation letters. Furthermore, we are grateful to Torben Lütje, Michael Melvin and Luca Rebeggiani in helping us to conduct the survey and we thank Thomas Cornelißen, Bernd Fitzenberger, Knut Gerlach, Dominik Hübler, Janice Madden, Gesine Stephan and an anonymous referee for helpful comments. Last, but not least, financial support by the Volkswagen Foundation is gratefully acknowledged.
} 


\section{Introduction}

This study examines the treatment of female and male asset managers who are responsible for the investment of several hundred millions if not billions of US dollars. Their activity is under very close scrutiny both from within the firm and from the customers. Asset managers' performance is measured daily and has to be presented to customers several times during the year. Insufficient performance leads to major reallocations of assets (Sirri and Tufano, 1998). There is thus no question that competition is very tough in this occupation and will limit discrimination of women at the workplace. However, despite reduced outright discrimination of women, concerns have been raised that discrimination may have become more subtle, either by purpose or possibly unconsciously (Blau et al., 2006). As a consequence we do not examine the compensation of asset managers but we take one step back and ask for determinants of the asset managers' fund size.

Fund size seems a natural choice to indicate treatment at the workplace as asset managers aim for getting large funds under their management responsibility. Size in the form of large assets is an indicator of success in this industry as size is in other industries as well, such as responsibility for many people, high revenue or large geographical areas. Accordingly, junior asset managers have to demonstrate their ability with small funds and only successful asset managers will get responsibility for increasingly larger funds. Larger funds tend to generate higher earnings for the asset management firms and thus higher income for its asset manager but not the opposite way round. ${ }^{1}$ Beyond the income dimension, large funds can also generate reputation for their managers, such as responsibility for large “flagship” funds.

\footnotetext{
1 See also Frank (1984) arguing that compensation may differ from performance or see Winter-Ebmer and Zweimüller (1997) emphasizing that "hierarchical status in a firm is not necessarily synonymous with pay ranking” (p.44) and that "sexist promotion practices may serve as a handy substitute for pay discrimination" (p.66).
} 
Therefore the volume of funds for which an asset manager is responsible is a clear indicator of her career success as asset management firms will allocate larger funds to more able managers only. Our investigation leads to the unexpected result that women manage smaller funds, even controlling for a set of relevant determinants, such as experience, education, position, type of fund and risk aversion.

We analyze the gender gap in three steps of increasing depth. First, we apply a standard framework to determine whether women are treated differently from men in this competitive occupation by testing whether women manage smaller funds. In order to get the necessary information we use a new broad data set compiled from a survey of asset managers in four countries, the United States, Germany, Switzerland and Italy. Second, we test by a quantile regression approach whether fund size differences between male and female asset managers are larger at the floor or at the ceiling of the fund size distribution. According to the glass ceiling hypothesis we expect stronger differences between men and women at the top of the fund size distribution, however, our evidence suggests the opposite. Third, we ask whether the treatment of women depends on firm size, where we hypothesize that larger firms enjoy more opportunities to avoid competitive pressures in some areas of the internal labor market. Following Yellen (1984) we suppose that employers can indulge costlessly their taste for discrimination among bad but not among good jobs since there is stronger competition between firms for the latter jobs. This mechanism may be supported by the financial press' main focus on the major large funds. We find, indeed, that women manage smaller funds than men (at the floor of the fund size distribution) within large firms only.

Our research is related to a wealth of studies analyzing the treatment of women at the workplace (e.g. Altonji and Blank, 1999). We differ from many studies by conducting an international within-occupation study considering typical demographic variables, job characteristics and individual attitudes in the total as well as in split samples. Our research is also related to a few studies analyzing the role of gender in asset management, including Atkinson 
et al. (2003), Niessen and Ruenzi (2007) or more indirectly Green et al. (2009) and Madden (2008). These studies uniformly find that women do not generate risk-adjusted fund returns different from men, which makes it less probable that female asset managers may be characterized by unobservable deficits in human capital.

The paper proceeds in the following way: Section 2 describes the data and the variables which are incorporated in our estimates. Results based on all available observations are presented in Section 3, results of subgroups in Section 4 and 5, whereas robustness tests are shown in Section 6. Section 7 concludes.

\section{Data, variables and descriptive statistics}

The data of this research stems from an anonymous questionnaire survey which was conducted in 2003/04 in the United States (USA), Germany (GER), Switzerland (SUI) and Italy (ITA). These countries were chosen, first, to cover a variety of important markets for asset management, including the largest, i.e. the U.S.; second, countries reflect our access to supportive institutions, such as the umbrella organizations of asset management firms in Germany and Italy. Each survey was preceded by a series of intensive interviews with the members of the target group and by a pretest. Also the broad response of 567 very timeconstrained asset managers may indicate that professionals took this survey seriously. ${ }^{2}$

Regarding the representation of firms Table 1 shows that about 175 asset management firms participated in the four countries. The response rate differs between countries and is highest in countries where we received support from the apex organizations. The highest absolute number of 74, however, comes from the US, where we approached—in light of our limited resources - the largest 250 firms only. In order to test representativeness we have

\footnotetext{
${ }^{2}$ The questionnaires were sent to the head of asset management in each firm who decided about further distribution. Usually we sent 2 to 6 copies by mail (depending on firm size) but sometimes the questionnaire was attached to an email. So we do not fully control the number of distributed questionnaires and accordingly cannot provide an exact response rate. To make a rough calculation, we addressed 433 firms and assuming that 5 questionnaires were distributed on average, this makes a total of 2,165 and yields a response rate in the order of $26 \%$.
} 
ordered participating firms — as far as we could identify responses—according to their assets under management and then compared the distribution of our sample with that of the market. ${ }^{3}$ There are no significant differences in any country.

Regarding the representation of asset managers Figure 1 shows the distribution of individual assets under management (FUND SIZE_c) for our four countries and for the (unweighted) total. ${ }^{4}$ The six categories are well represented in all countries, although some differences between markets become obvious.

In order to explain gender differences in managed fund size (FUND SIZE) we incorporate as set of potentially useful determinants. These determinants may be grouped into three categories, i.e. demographics, job characteristics and individual attitudes. Demographic variables primarily have an impact on human capital. The job characteristics, such as working in specific areas of asset management, may impact segregation and, finally, there are individual attitudes which seem to be obviously related to job performance.

Starting with demographic determinants of FUND SIZE, career success is naturally related to increasing age and better education. ${ }^{5}$ The true driver of success, however, is not just age but rather job experience (e.g. O’Neill and O’Neill, 2005). Picking up the argument made by Becker (1985) marital status, too, may be influential as far as it reflects a higher attention towards housework, including in particular taking care of children ${ }^{6}$. Finally, we consider the hierarchical position that an asset manager has reached as this is very closely related to FUND SIZE and thus serves as a powerful proxy to capture otherwise hidden abilities.

\footnotetext{
${ }^{3}$ Despite the opportunity to keep anonymity almost all firms have signalled their participation although the fund managers themselves always stayed anonymous.

${ }^{4}$ Volume figures in the US were of course compiled in US dollars, which are converted into Euros at the exchange rate of one reflecting market rates directly before the survey in 2002 and 2003.

5 The importance of good education has been shown for asset managers by Chevalier and Ellison (1999), although they find that the quality of the degree-granting institution matters and not so much as a degree as such. Menkhoff et al. (2006) find a positive impact of experience on investment behaviour.

${ }^{6}$ The number of children would be a better indicator to measure this influence. This information is not available. However, the interaction between the marital dummy, the gender dummy and the age of the fund manager could give some evidence. Preliminary investigations have shown that the coefficient of this interaction variable is negative as expected, however, completely insignificant.
} 
Job characteristics may also influence fund size. We control for three potential influences in this respect. First, size of the asset management firm could be important if larger firms specialize on larger funds. Second, the kind of assets managed may systematically influence the volumes under management. It seems plausible in this respect that equities typically require more attention than bonds or money market instruments as equities differ in more dimensions to each other than different bonds do. Please, note that asset managers classify themselves according to their main responsibility. Third, the kind of fund, i.e. mutual or pensions fund, may be important too. Mutual funds mainly address individual investors and are thus debated for example in investor magazines, whereas pension funds and related other funds mainly have professional investors, such as life insurance firms who delegate part of their asset management to specialists.

As a third group of characteristics we consider attitudes of asset managers. ${ }^{7}$ The most important and robust variable is usually the volume of work which we approximate via a selfstated number of working hours per week. Women—more than men-prefer working fewer hours in favor of time being left for other activities (Booth and van Ours, 2008). Furthermore, it has been found that the basis for compensation may influence the treatment of women in the sense that a more objective basis induces less fear of discrimination than a more subjective basis (Heywood and Jirjahn, 2002). Accordingly, we consider a proxy for this effect by measuring the relative strength of subjective assessment for the size of bonus payments in relation to relative fund performance ${ }^{8}$. As a final variable influencing career success Dohmen et al. (2009) find that lower personal risk aversion is an important attitude explaining success. Consideration of this variable seems particularly important here as women tend to be more

\footnotetext{
7 Please note that asset managers have no incentive for strategic answering as responses were given directly to the researchers in anonymous form. Anonymity has a price in that we cannot link our data to objective measures of fund returns. We emphasize, however, that gender is no determinant of performance, i.e. risk-adjusted returns, according to available evidence (see footnote 2).

${ }^{8}$ Subjective base for the size of bonus payments means that the criterion is not clear for the fund managers that the superior decides about the bonus payment. An objective base is completely comprehensible for the fund manager. In our survey it is asked for the degree of objective and subjective base (see table 2, BONUS1 and BONUS2) and we determine the difference between these two categorical variables, measured by count data.
} 
risk averse than men in general. ${ }^{9}$ In order to distinguish this effect from risk aversion being related to investment decisions we also use as a control the degree of preferred investment risk.

Variable definitions and their coding are shown in Table 2. The resulting information about participating asset managers is presented in an aggregated way in Table 3 , starting with the average individual volume of assets under management. The last columns of Table 3 show the average figures for male and female asset managers. It is obvious that women manage much smaller funds than men. This is just descriptive information though. The next row presents the share of female asset managers, varying between $8.1 \%$ in Switzerland and $16.3 \%$ in Italy. The overall low representation of women in asset management is substantially below the share of female students in finance or economics. One reason for this segregation may be that asset management has a lot of "male” attributes, such as being analytical and impersonal, requiring tough negotiations and willing to take risks.

Further information shows that the average respondent (equal weighting of countries) is about 35 - 42 years old, has almost ten years of professional experience in asset management and is married (about $58 \%$ of respondents). About $80 \%$ of asset managers have a university degree. Possibly more important for the relevance of our data set is the fact that most respondents have a senior position (84\%), starting with senior asset managers up to many chief investment or executive officers answering the questions.

With regards to the representation of various segments of fund management (see Table 3), the sample comprises — with marked differences between countries - managers of equity and other funds (bonds and money market) in almost equal proportions. Similarly mutual fund managers are well represented with almost $40 \%$, the remaining respondents managing either

\footnotetext{
${ }^{9}$ There is a lot of evidence from various angles, including Barber and Odean (2001), Dwyer et al. (2002), Eckel and Grossman (2008), Olsen and Cox (2001), Sunden and Surette (1998), Niessen and Ruenzi (2007). Schubert et al. (1999) find, however, that a gender difference may be subject to framing.
} 
pension (and other special) funds or both, i.e. mutual and pension funds. Also managers of small and large asset management firms are well covered as we will analyze later.

Finally, in order to learn more about the hidden characteristics of asset managers we ask them about four items of individual attitudes and work patterns (see towards bottom of Table 3): first, regarding their weekly working hours—indicating volume of work; second, regarding the relative importance of subjective versus objective performance-based bonus remuneration; third, regarding their general risk aversion by way of a lottery equivalent—as an indicator of willingness to accept risk and thus to be possibly more successful in career development; fourth and finally, regarding asset managers' propensity to act less risk averse in investment decisions. The results in Table 3 demonstrate that working hours per week are evidently higher than in most other occupations, that working time in Europe-in this occupation as in others-is lower than in the US and that women work less than men on average. Moreover, bonuses are a bit more often determined by subjective assessments than by relative fund performance and asset managers do not seem particularly risk averse. The latter is indicated by self assessment as well as by their stated risk aversion as shown by the last item (RISK_general) indicted: respondents require a compensation of less than 2000 Euro when 1000 Euro are at stake, i.e. a factor of below 2, whereas the general population requires rather a factor above 2 (e.g. Tversky and Kahneman, 1992). It is worth noting that bonuses of female asset managers are to the same extent based on subjective assessment than for men (see Table 3, line BONUS). This indicates that employers do not have a propensity to discriminate female managers via subjective assessment.

Overall, the survey data should provide reliable and largely representative information for the following analyses.

\section{Results for the entire sample}


This section develops the main finding, that women manage smaller funds, in three steps. First, we show relations between variables and asset managers' responsibility for fund volume (FUND SIZE_c). Second, we provide regressions explaining fund size, and, third, we run a standard Oaxaca Blinder decomposition in order to better identify the unexplained difference of fund size between female and male asset managers.

Our statistical measures of association between fund size and personal or job-specific variables which could be determinants of fund size give the expected results (see Table 4): in particular, female asset managers have smaller volumes than their male colleagues. However, there are some cross-country differences, as the correlation is not significant in the U.S. and in Switzerland. Beyond this, asset managers have responsibility for larger volumes if they are older, more experienced, in a more senior position, work in a larger firm and work more hours per week. The effect of a graduate degree is insignificant for three countries, but holds in Germany and in the total sample. The degree of risk aversion does not seem to be correlated with FUND SIZE. Equity fund managers have smaller volumes than bond and money market fund managers, mutual fund managers tend to have smaller volumes than others.

Next, we put all of these possible determinants into a multivariate regression. Here we use FUND SIZE in its logarithmic form because nonlinear relations are expected due to saturation effects. ${ }^{10}$ The resulting regression, given in $\underline{\text { Table } 5}$ as specification (1), provides good overall explanatory power for this type of approach with an R-squared of 0.343 . Moreover, most variables are significant and coefficient signs confirm ex ante expectations. In comparison to the relations presented in Table 4, there are a few changes. Interestingly, better education has only an insignificant impact on fund size in the multivariate regression and also fund type (mutual fund or other type) does not seem to be important anymore. Finally, country dummies show that Swiss asset managers have systematically smaller assets under manage-

\footnotetext{
10 Preliminary empirical investigations confirm this. The fit in models with FUND SIZE as dependent variable instead of $\log$ (FUND SIZE) is much worse and several coefficients are insignificant. Saturation means that the influence of all determinants on FUND SIZE is restricted and cannot be infinite. Therefore, the quantitative effect cannot be linear over the entire range.
} 
ment than their German colleagues. Most interesting for our research is the fact that the coefficient of the FEMALE variable is highly significant and indicates that women do indeed manage smaller funds, even controlling for a large set of potential determinants of fund size.

Several of our variables have neither been significant in the bivariate relations nor in specification (1). We thus aim for a more parsimonious specification. We reduce the number of variables included step by step according to their lowest level of significance each until we realize specification (2). Fortunately, this specification is quite robust in three ways. First, it seems to be independent from the ordering in which variables are excluded. Second, all variables included prove to be very robust to the set of variables being included in the regression (with some qualification for the variable "mutual fund" though). Third, the variable "POSITION” does not seem to be endogenous. ${ }^{11}$

With this parsimonious benchmark specification at hand, we apply the standard OaxacaBlinder decomposition to our data. Necessary for this calculation are separated estimates for men and women based on the specification in column 2, Table $5 .{ }^{12}$ We find that about $45 \%$ of the gender gap in fund size is explained by their different endowment but that $55 \%$ remain unexplained in our approach. ${ }^{13}$ This indicates that female asset managers may be subject to discrimination —in the conventional sense of describing the unexplained part of the gender gap in fund size-which seems surprising to us in this highly competitive environment of asset management. Competition in asset management should be tough as outcomes can be quite precisely measured. Inferior outcomes lead to money outflows (or relatively less in-

${ }^{11}$ One could argue that the regressor "POSITION" is endogenous, so that FUND SIZE has also influence on POSITION (larger fund size leads to higher probability of being promoted). However, the Hausman test does not reject exogeneity. The test is based on the comparison of a 2SLS estimator and the OLS estimator where POSITION is determined by MARRIED, AGE, GRADUATE, BONUS and RISK_invest. The CHI² statistic is 8.89 and the probvalue 0.54 .

12 Detailed coefficient estimates are not presented in the tables as the t-statistics of the female coefficient estimates are insignificant due to the limited number of women in the sample. Fortunately, this does not influence the Oaxaca-Blinder decomposition. The comparison demonstrates strong differences between male and female coefficients of the regressor POSITION. The higher is position the larger are the funds for which male managers are responsible whereas this relation is much weaker for women.

${ }^{13}$ The result is almost identical when applying the Juhn et al. (1993) decomposition. Accordingly, $\mathrm{T}=1.0652$, $\mathrm{Q}=0.4162, \mathrm{P}=0.5284, \mathrm{U}=0.1207$, where $\mathrm{T}=$ total difference, $\mathrm{Q}=$ contribution of differences in observable quantities, $\mathrm{P}=$ contribution of differences in observable prices (i.e. consistent with discrimination) and $\mathrm{U}=$ contribution of differences in unobservable quantities and prices (i.e. may partially be due to discrimination). 
flows) and thus to reduced income as contracts reward assets under management with a linear management fee.

Possible reasons for this discrepancy between men and women are discussed by Niessen and Ruenzi (2007) who analyze net inflows into female or male managed funds: fund investors may have negative preconception about the abilities of female asset managers, fund management companies may discriminate by not advertising female managed funds, fund brokers may assess female asset managers as less able or financial press may report less about female managed funds. Madden (2008) emphasizes the possibility that fund management firms may discriminate against women by the assignment of complementary inputs. She mentions office amenities, support staff, the title that a broker is allowed to use on her business card, size and quality of the broker's office (which impacts work efficiency and signals reputation to customers). Of course, we cannot rule out the possibility that either omitted variables or measurement error explain partially our result of the unexplained gender gap, although our study covers core variables put forward by the literature (e.g. O’Neill and O’Neill, 2005), such as experience and working hours.

According to this argument one could speculate whether women have unobserved characteristics that reduce their chances of being successful asset managers. Such a characteristic might be “confidence in investment decisions” (Estes and Hosseini, 1988). Another characteristic sometimes mentioned is that women tend to "shy away from competition" (Niederle and Vesterlund, 2007, see also Gneezy et al., 2003, Dohmen and Falk, 2006). In the asset management industry, however, women are grossly underrepresented and those who chose to work there obviously need confidence in their decisions and willingness to stand in the tournament competition.

Therefore, further analyses seem useful in order to understand the unequal treatment of women. As a step in this direction we split our sample and test possible implications which cannot be examined with the entire sample. 


\section{Results for specific groups: individual assets under management}

Studies on the treatment of women typically find that unequal treatment increases with the prestige of jobs (Winter-Ebmer and Zweimüller, 1997). We use our sample to test this hypothesis in a within occupation setting. Interestingly, we find the reverse of the "glass ceiling hypothesis”, a phrase used by Albrecht et al. (2003) showing that the gender wage gap in Sweden increases with higher wages and in particular at the top end: the smaller the fund size the more obvious does unequal treatment to the disadvantage of women become.

In order to test whether the relation between the treatment of women and the quality of jobs differs with respect to fund size, we apply a quantile regression approach considering the variables from our benchmark regression, i.e. specification (2) in Table 5. Results presented in $\underline{\text { Table } 6}$ show all coefficients, including those of the FEMALE variable, for the quantiles being distinguished. The FEMALE coefficients are insignificant at the top of the fund size

distribution, at the $90^{\text {th }}$ and $75^{\text {th }}$ percentile, and become almost consistently larger and significant towards the bottom at the $25^{\text {th }}$ and $10^{\text {th }}$ percentile, and thus reveal a clear pattern. Reassuringly, this pattern does not come at the cost of unwanted changes in the other variables although some variables become insignificant.

The decomposition into endowment and unexplained effects is also applied to the quantile regression approach. We find the following interesting result: The higher the quantile the lower is the unexplained part of fund size differences between males and females. For the 0.9 quantile only 28 percent are explained by this effect while the 0.1 quantile documents even an endowment advantages for women.

In contrast to this finding, it has been argued that discriminatory practices are more prevalent among better jobs. Reasons for such a “glass ceiling”, i.e. unobserved barriers at higher hierarchical levels, could be family background influences which have negative effects for women (Bell et al., 2008). This hinders women to be promoted in upper hierarchical levels 
and if so only under high costs in the sense of their "overqualification". These barriers contribute also to the increasing gender gap within firm’s hierarchy. There is some evidence for the "glass ceiling" hypothesis with respect to wages in the literature (e.g. Albrecht et al., 2003, Hübler, 2005, Arulampalam et al., 2007, de la Rica et al., 2008).

However, it is not fully obvious that the hypothesis of increasing discrimination within a firm's hierarchy—-here measured by the individual volume of administered assets—should hold in a comparatively competitive environment such as the asset management industry. Tough competition harms those firms practicing discrimination of women more severely than in less competitive areas (see Meng, 2004). Somewhat differentiating this argument, we do not expect that competition is equally pressing at all levels of a firm's hierarchy: first, discrimination is less costly per employee in the lower positions (although not necessarily in relative terms) so that firms can easier practice market power there. ${ }^{14}$ Second, the demand for jobs is higher at the top end of the hierarchy which leads to more competition among firms respectively. Third, we speculate that top jobs may be more in the public eye which could also contribute to respective costs of discrimination. However, we have no clear evidence for this claim. Perhaps this is only true for a few star performers featured in the financial press. Accordingly, competition makes discrimination at the top end of the spectrum more costly and may rather reduce discrimination for the best jobs, i.e. for the employees with the largest individual funds. Thus we argue that also the opposite of the glass ceiling hypothesis may hold.

Similar results to ours are found in the analysis of gender wage gap by Bonjour and Gerfin (2001) in Switzerland and by de la Rica et al. (2008) for less-educated in Spain. The latter call this phenomenon "floor pattern" and argue that it can be explained by statistical discrimination when specific training is required to perform well on a job.

\footnotetext{
${ }^{14}$ If funds are managed by second best managers as firms discriminate women, this leads to relatively worse performance and then to a relatively declining fund volume. Any relative loss of competitiveness and volume is more severe at a large than at a small fund.
} 
As this floor pattern is a rather unusual finding in the overall literature, we will analyze it in more detail.

\section{$5 \quad$ Results for specific groups: individual assets and firm size}

This section examines empirically whether the fact that smaller funds are managed by female asset managers is related to firm size. For this purpose we reproduce the quantile regression approach of the preceding section, but now being further disaggregated into smaller and larger firms. We split firms into the first three versus the last three categories as documented in Table 2, i.e. the dividing line is total assets under management of 20 billion Euro. $\underline{\text { Table } 7}$ shows results which indeed reveal that the earlier finding on FUND SIZE (see Section 4 above) has to be rooted in practice at larger firms: it is asset managers with smaller FUND SIZE at larger firms where the FEMALE variable has explanatory power. Gender neither seems to be important in smaller firms nor for asset managers with great responsibilities at larger firms.

This finding is consistent with a specific floor gender gap hypothesis, namely only for large firms. Accordingly, small firms cannot afford costly discriminatory practices as single asset managers make larger marginal contributions to the firm’s revenues. By contrast, larger firms can more easily survive with some degree of inefficient behavior as long as inefficiencies do not occur in core areas. With respect to our case here, and referring to Section 4, larger firms can easier afford a (possibly inefficient) worse treatment of women than small firms as long as it applies to the smaller funds within large firms. From this perspective, discrimination will occur in more marginal areas of the firm and thus does not harm so much. Of course, the argument applies in the same manner if we assume that larger firms enjoy some market power. More generally, we carry over the arguments from above Section 4-i.e. small funds go along with lower costs, less hiring competition and less visibility—and argue that large em- 
ployers will tend to concentrate their discrimination policy on jobs at the bottom of the firm's hierarchy.

We note that our finding is not fully consistent with Niessen and Ruenzi (2007) who ar-

gue-with data for the U.S. - that large companies are more likely to be sued in anti-

discrimination lawsuits and cater more institutional investors who ask for workforce diversity. Following these arguments one would expect that women managing large and small funds are not discriminated in large companies. Our finding indicates that the niche where women manage smaller funds is noticed with less attention, so that discriminatory practices may survive. We cannot rule out, too, that the niche we identify is exactly the place where women with less energy for their job are clustering.

\section{Robustness}

In order to test the robustness of our results we proceed in three directions, i.e. we examine new methods, new sample splits and new specifications. Our main findings seem to be robust.

Regarding our method of choice, we have preferred a standard OLS approach which has the advantage of allowing further extensions—-such as decomposition and the quantile regression—and the advantage of allowing better comparability with earlier research. If individual volume is used in classified or in interval-coded form, however, in this case according to six categories (FUND SIZE_c - see Table 2), an ordered probit approach or an interval regression (see Wooldridge 2002, p. 509) should be applied. Specification (3) and (4) in the above introduced Table 5 provides coefficients and their significance levels for this alternative estimation method. As can be seen, the findings from this alternative approach are very similar.

When using a classified dependent variable the quantile estimator is not suitable. An alternative is provided by the generalized ordered probit estimates (Boes and Winkelmann 2006) where separate estimates of each category of individual volume of assets (FUND 
SIZE_c) are determined. The results which are not presented in the tables demonstrate the following: the lower is the category of FUND SIZE_c, the stronger is the gender effect and the higher is the p-value. In high categories the gender effect is statistically negligible. This is an important robustness check which supports our results in Table 6.

Regarding a second direction of robustness tests, we examine further splits of our sample. Section 5 introduces firm size as an indicator of the degree of competition in the market and one may speculate about further information in our sample serving the same purpose (see Table 8). Accordingly, we hypothesize that the U.S. market may be more competitive than the three other markets under consideration. One reason for the high competitiveness in the U.S. market, beyond a generally high degree of sophistication due to a capital market based financial system, stems from the fact that the large U.S. asset management firms are typically independent institutions, developing their own company agenda, whereas asset management firms often belong to bank conglomerates in continental Europe; as subsidiaries, their company policy depends on the banks’ preferences. There is indeed evidence consistent with this view as the FEMALE coefficients in Panel A of Table 8 indicate. We hesitate, however, to further differentiate the European countries in this respect. Examining another implication, funds basically address either more individual investors (mutual funds - MFUND) or professional investors (pension funds - PFUND), where the latter provide a more competitive environment for the asset managers. The respective split in the sample and separated regressions indicate that the FEMALE coefficient is significant in the less competitive segment (Table 8, Panel B). We are aware though that this distinction is blurred as sometimes professionals invest in mutual funds and individual investors allocate their pension wealth to particular funds. However, our finding is not fully consistent with a rational response of firms towards individual investors' discrimination against female fund managers. As a last exercise in this direction, we hypothesize that the competitive pressure found in Section 5 may also be reflected in hierarchical position in the sense that differential treatment of women disappears at 
the top. Panel C of Table 8 shows that differences in this respect are not strong, however, they are consistent with the hypothesis.

Nevertheless, it may somewhat unexpected-according to Panel C of Table 8-that the lowest ranking female junior managers manage funds of equivalent size to their male counterparts, yet women in the lower quantiles get smaller funds than their male colleagues - see Table 6. Therefore, we examine the lowest quantile in more detail again. We split the 0.1 quantile into subsamples of POSITION=1 (junior manager) and POSITION=2 (senior manager) and estimate the last column of Table 6 separately. Indeed, the only significant difference between men and women is in the subsample of senior managers, i.e. consistent with Table 8 (the t-statistic of the female coefficient is 0.08 and -4.06 respectively).

Regarding our third direction of robustness tests we perform a large set of alternative specifications. There are, indeed, some variables which may be sometimes significant depending on specification but none of them is robust so that it would deserve inclusion in the benchmark specification (see Table 4, specification 2). Moreover, we have also investigated the influence of interactions with the gender variable and we have estimated separated models for men and women which are the base of the Oaxaca-Blinder decomposition (see Section 4). In most cases interaction effects are statistically insignificant. Finally, a recursive model with a position equation and the individual volume of administered assets is estimated. The coefficient of the FEMALE variable in the latter equation remains negatively significant. Overall, our main findings seem to be robust.

\section{Conclusion}

Asset managers aim for getting large funds under their responsibility, an ambition which seems natural in this competitive field where prestige, promotion, prospects and renumeration are strongly linked to the fund size under individual management. In our sample of 467 asset managers from four countries a large set of plausible determinants of the individual 
volume of assets under management (FUND SIZE) is analyzed. Our investigation shows that managers with experience, in high positions and long working time manage larger funds. Surprisingly, gender is also one of these determinants as men tend to manage larger funds than women. So far, our study contributes to a large body of literature documenting unequal treatment of women and men at the workplace, here for a particular occupation which has not yet been examined in this way.

However, this study also provides more general insights: first, the occupation being analyzed is characterized by tough competition among asset managers and asset management firms. It is thus even more surprising that our finding seems to be so conventional. Second, we analyze unequal treatment of the sexes for the different fund volumes. The glass ceiling hypothesis expects more inequality at the top but our evidence is against this expectation. Third, more unequal treatment may be expected in larger firms, which is indeed the case in our sample. Moreover, the last two effects discussed add up in the sense that unequal treatment is most pronounced for smaller fund sizes in large firms. A set of robustness checks supports the main findings.

Much of our evidence which we relate to the market power of large firms can also be understood as supporting a "visibility” hypothesis. Accordingly, unequal treatment of the sexes occurs less where visibility is higher, that is for top asset managers-with high asset volumes — and in small firms where the treatment of individuals is rather less anonymous. Further investigations with new data can help to clarify the mechanism behind our robust empirical outcome. 
TABLE 1. On the representativeness of responses

\begin{tabular}{lcccc}
\hline & USA & GER & SUI & ITA \\
& & & & \\
Number of responses & 149 & 263 & 42 & 112 \\
Number of responding firms & 74 & 51 & 18 & 32 \\
Share of responding asset managing firms & $29.6 \%$ & $77.3 \%$ & $29.0 \%$ & $58.2 \%$ \\
& -1.213 & -0.669 & -0.385 & -0.403 \\
$\begin{array}{l}\mathrm{H}_{0} \text { : Structure of responding firms equals } \\
\text { structure of the market }\end{array}$ & $(0.225)$ & $(0.503)$ & $(0.700)$ & $(0.687)$ \\
\hline
\end{tabular}

${ }^{(a)}$ Firms are characterized by asset under management. The figures are the z-value of the Mann-Whitney U-test and the p-value in parentheses.

Figure 1. Individual assets under management

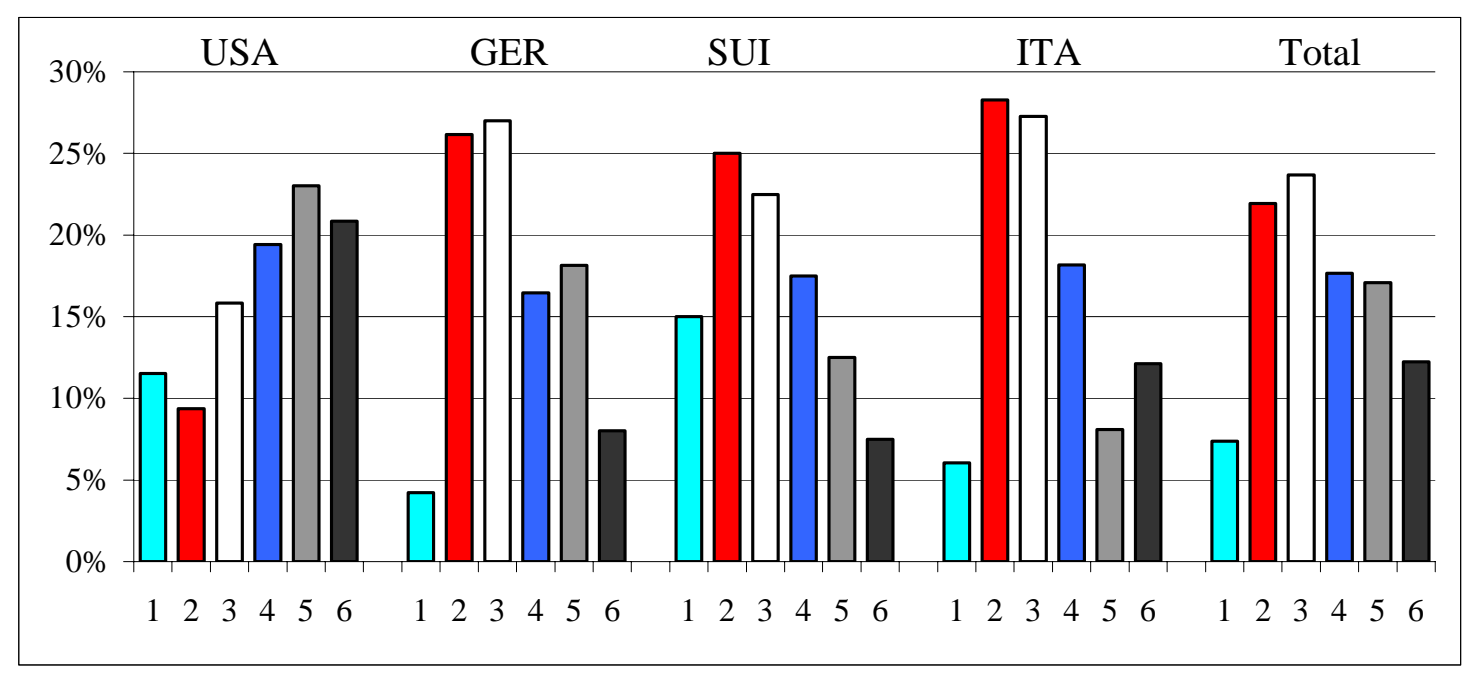

Note: Answer about "personal responsibility for assets under management” are given in six categories (in million of Euro): 1 (<50), 2 (50-250), 3 (250-1.000), 4 (1.000-2.500), 5 (2.500-10.000), 6 (>10.000). 


\section{TABLE 2. $\quad$ Variable definitions}

FUND SIZE $\quad$ Fund size under individual management (in million of $€$ )

FUND SIZE_c Classified FUND SIZE ( $=1$, if $<50$ million $€$; $=2$, if $50-<250$; =3, if 250$<1,000)$; $=4$, if $1,000-<2,500 ;=5$, if $2,500-<10,000 ;=6$, if $>=10,000$ ) Assumptions: class midpoints are class means, open classes 1 and 6 have means of 30 and 15,000 respectively.

FEMALE $\quad$ Gender (=1, if female; $=0$, if male)

AGE $\quad$ Age classified $(=1$, if age is $<31 ;=2$, if 31-35; =3, if 36-40; =4, if 41-45; $=5$, if $46-50 ;=6$, if $>50$ )

EXPERIENCE Professional experience in asset management $(=1$, if $<4$ years; $=2$, if $4-6$; $=3$, if 7-9; $=4$, if $10-12 ;=5$, if $13-15 ;=6$, if $>15$ )

MARRIED Marital status (=1, if married; $=0$ otherwise)

GRADUATE $\quad$ Educational level $(=1$, if graduate degree; $=0$ otherwise)

POSITION Current position within the company (=1, if junior asset manager; $=2$, if senior asset manager; $=3$, if head of asset management team; $=4$, if chief investment officer/CEO)

VOL_firm Classified firm's total volume of assets under management $(=1$, if $<5$ billion of $€$; $=2$, if 5-10; =3, if $>10-20$; $=4$, if $>20-50$; =5, if $>50-100$; $=6$, if $>100$ )

EQUITIES Major investment segment (=1, if major segment is equities; $=0$ otherwise)

MFUND Type of managed fund (=1, if mutual fund; $=0$ otherwise)

WORKING Average working hours per week ( $=1$, if $<41$ hours; $=2$, if $41-45 ;=3$, if HOURS $\quad 46-50 ;=4$, if $51-55 ;=5$, if $56-60 ;=6$, if $>60)$

BONUS1 Bonus determination is based on relative fund performance $(=1$, if highest relevance; ...; =6, if no relevance)

BONUS2 Bonus determination is based on subjective assessment by superiors and colleagues ( $=1$, if highest relevance; $\ldots ;=6$, if no relevance)

BONUS BONUS1 - BONUS2

RISK_invest "Please classify your personal risk-taking: In respect of professional investment decisions, I mostly act ... ” (=1, if very risk averse, ..., =6, if little risk averse)

RISK_general "Imagine someone offers you a bet and the odds are fifty-fifty. You will have to pay 1,000 Euro/USD from your personal account, if you lose. What would be the minimum amount you would expect to win to lure you into accepting the bet? At least ... Euro/USD.”

RISK_general_c Classified RISK_general $(=1$, if bet $<=1000$; $=2$, if $>1000-1500$; $=3$, if $>1500-2500$; $=4$, if $>2500-5000 ;=5$, if $>5000-25000 ;=6$, if $>25000$ ) 


\section{TABLE 3. Descriptive statistics}

\begin{tabular}{|c|c|c|c|c|c|c|c|}
\hline & TOTAL & USA & GER & SUI & ITA & WOMEN & MEN \\
\hline $\begin{array}{l}\text { AVERAGE FUND SIZE } \\
\text { (in million of } € \text { ) }\end{array}$ & 3453 & 4925 & 2810 & 2580 & 3261 & 1750 & 3657 \\
\hline $\begin{array}{l}\text { FEMALE } \\
\text { (in \%) }\end{array}$ & 10.7 & 11.7 & 8.6 & 8.1 & 16.3 & 100 & 0 \\
\hline $\begin{array}{l}\text { AVERAGE AGE } \\
\text { (in years) }\end{array}$ & 37.6 & 41.8 & 35.9 & 38.2 & 35.1 & 35.3 & 37.8 \\
\hline $\begin{array}{l}\text { AVERAGE EXPERI- } \\
\text { ENCE } \\
\text { (in years) }\end{array}$ & 9.1 & 12.8 & 7.2 & 9.9 & 8.0 & 7.9 & 9.2 \\
\hline $\begin{array}{l}\text { MARRIED } \\
\text { (in \%) }\end{array}$ & 57.8 & 78.1 & 52.3 & 45.9 & 46.3 & 40.0 & 60.0 \\
\hline $\begin{array}{l}\text { GRADUATE } \\
\text { (in \%) }\end{array}$ & 83.7 & 79.7 & 84.2 & 75.7 & 92.5 & 90.0 & 83.0 \\
\hline $\begin{array}{l}\text { NON-JUNIOR POSI- } \\
\text { TION } \\
\text { (in \%) }\end{array}$ & 83.6 & 70.3 & 91.9 & 82.5 & 66.0 & 79.1 & 77.7 \\
\hline $\begin{array}{l}\text { AVERAGE VOL- } \\
\text { UME_firm } \\
\text { (in billion of } € \text { ) }\end{array}$ & 58.9 & 55.0 & 63.3 & 102.9 & 32.7 & 47.5 & 60.3 \\
\hline $\begin{array}{l}\text { EQUITY FUND MAN- } \\
\text { AGERS (in \%) }\end{array}$ & 53.5 & 55.5 & 60.8 & 48.6 & 32.5 & 64.0 & 52.3 \\
\hline $\begin{array}{l}\text { MUTUAL FUND } \\
\text { MANAGERS (in \%) }\end{array}$ & 38.8 & 31.3 & 33.8 & 37.8 & 65.0 & 60.0 & 36.2 \\
\hline $\begin{array}{l}\text { WORKING HOURS } \\
\text { (per week) }\end{array}$ & 49.8 & 52.2 & 49.1 & 48.2 & 48.6 & 48.1 & 50.0 \\
\hline $\begin{array}{l}\text { BONUS } \\
\text { (share subjective risk) }^{1}\end{array}$ & 58.9 & 50.8 & 67.1 & 64.9 & 46.3 & 58.0 & 59.0 \\
\hline $\begin{array}{l}\text { RISK_invest } \\
\text { (share of risk averse) }^{2}\end{array}$ & 45.2 & 43.0 & 47.7 & 43.2 & 42.5 & 48.0 & 44.8 \\
\hline $\begin{array}{l}\text { RISK_general } \\
\text { (median) }\end{array}$ & 2000 & 1750 & 1500 & 2000 & 2000 & 2000 & 1500 \\
\hline
\end{tabular}

${ }^{1}$ Share BONUS1 $\geq$ BONUS2, i.e. where subjective assessment is more important than relative fund performance.

${ }^{2}$ Share of response categories 1-3. 
TABLE 4. Measures of association (Kendall's tau) - relations between classified individual volume (FUND SIZE_c) and other variables separated by countries

\begin{tabular}{|c|c|c|c|c|c|}
\hline & Total & USA & GER & SUI & ITA \\
\hline FEMALE & $\begin{array}{c}-0.149 * * * \\
(0.040)\end{array}$ & $\begin{array}{c}-0.065 \\
(0.081)\end{array}$ & $\begin{array}{c}-0.202^{* * *} \\
(0.050)\end{array}$ & $\begin{array}{c}0.153 \\
(0.100)\end{array}$ & $\begin{array}{c}-0.323^{* * *} \\
(0.075)\end{array}$ \\
\hline AGE & $\begin{array}{c}0.197 * * * \\
(0.036)\end{array}$ & $\begin{array}{c}0.222^{* * *} \\
(0.063)\end{array}$ & $\begin{array}{c}0.137 * * \\
(0.055)\end{array}$ & $\begin{array}{c}-0.041 \\
(0.130)\end{array}$ & $\begin{array}{c}0.217 * * \\
(0.089)\end{array}$ \\
\hline EXPERIENCE & $\begin{array}{c}0.237 * * * \\
(0.036)\end{array}$ & $\begin{array}{c}0.304^{* * *} \\
(0.068)\end{array}$ & $\begin{array}{c}0.242 * * * \\
(0.053)\end{array}$ & $\begin{array}{c}0.168 \\
(0.129)\end{array}$ & $\begin{array}{c}0.291 * * * \\
(0.089)\end{array}$ \\
\hline MARRIED & $\begin{array}{c}0.099 * * \\
(0.042)\end{array}$ & $\begin{array}{c}0.033 \\
(0.079)\end{array}$ & $\begin{array}{c}0.151 * * \\
(0.060)\end{array}$ & $\begin{array}{c}0.000 \\
(0.150)\end{array}$ & $\begin{array}{c}-0.054 \\
(0.102)\end{array}$ \\
\hline GRADUATE & $\begin{array}{c}0.107 * * * \\
(0.040)\end{array}$ & $\begin{array}{c}0.073 \\
(0.082)\end{array}$ & $\begin{array}{l}0.137 * \\
(0.058)\end{array}$ & $\begin{array}{c}0.084 \\
(0.123)\end{array}$ & $\begin{array}{c}0.159 \\
(0.079)\end{array}$ \\
\hline POSITION & $\begin{array}{c}0.301 * * * \\
(0.040)\end{array}$ & $\begin{array}{c}0.222 * * * \\
(0.81)\end{array}$ & $\begin{array}{c}0.404^{* * *} \\
(0.053)\end{array}$ & $\begin{array}{c}0.195 \\
(0.142)\end{array}$ & $\begin{array}{c}0.212 * * \\
(0.095)\end{array}$ \\
\hline VOL_firm & $\begin{array}{c}0.296 * * * \\
(0.033)\end{array}$ & $\begin{array}{c}0.364 * * * \\
(0.064)\end{array}$ & $\begin{array}{c}0.332 * * * \\
(0.049)\end{array}$ & $\begin{array}{c}0.354^{* * *} \\
(0.117)\end{array}$ & $\begin{array}{c}0.273 * * * \\
(0.077)\end{array}$ \\
\hline EQUITIES & $\begin{array}{c}-0.116 * * * \\
(0.040)\end{array}$ & $\begin{array}{c}0.002 \\
(0.080)\end{array}$ & $\begin{array}{c}-0.194 * * * \\
(0.058)\end{array}$ & $\begin{array}{l}-0.165 \\
(0.148)\end{array}$ & $\begin{array}{l}-0.128 \\
(0.096)\end{array}$ \\
\hline MFUND & $\begin{array}{c}-0.132 * * \\
(0.066)\end{array}$ & $\begin{array}{c}0.059 \\
(0.076)\end{array}$ & $\begin{array}{c}-0.108 * \\
(0.062)\end{array}$ & $\begin{array}{c}-0.191 \\
(0.149)\end{array}$ & $\begin{array}{c}-0.202 * * \\
(0.100)\end{array}$ \\
\hline WORKING HOURS & $\begin{array}{c}0.251 * * * \\
(0.038)\end{array}$ & $\begin{array}{c}0.202 \\
(0.075)\end{array}$ & $\begin{array}{c}0.280 \\
(0.053)\end{array}$ & $\begin{array}{c}0.024 \\
(0.156)\end{array}$ & $\begin{array}{c}0.247 \\
(0.088)\end{array}$ \\
\hline BONUS & $\begin{array}{c}-0.083^{* *} \\
(0.041)\end{array}$ & $\begin{array}{c}-0.085 \\
(0.079)\end{array}$ & $\begin{array}{l}-0.091 \\
(0.060)\end{array}$ & $\begin{array}{c}0.058 \\
(0.143)\end{array}$ & $\begin{array}{l}-0.003 \\
(0.105)\end{array}$ \\
\hline RISK_invest & $\begin{array}{c}-0.022 \\
(0.036)\end{array}$ & $\begin{array}{c}-0.062 \\
(0.067)\end{array}$ & $\begin{array}{c}0.019 \\
(0.054)\end{array}$ & $\begin{array}{c}-0.264^{* *} \\
(0.114)\end{array}$ & $\begin{array}{c}0.077 \\
(0.078)\end{array}$ \\
\hline RISK_general_c & $\begin{array}{c}-0.013 \\
(0.036)\end{array}$ & $\begin{array}{c}-0.101 \\
(0.067)\end{array}$ & $\begin{array}{c}0.020 \\
(0.053)\end{array}$ & $\begin{array}{c}-0.050 \\
(0.146)\end{array}$ & $\begin{array}{c}-0.007 \\
(0.094)\end{array}$ \\
\hline
\end{tabular}

Notes: *** denotes significance at the 0.01 level. ** denotes significance at the 0.05 level. * denotes significance at the 0.10 level. Standard errors are in parentheses. 
TABLE 5. Estimates of individual fund size

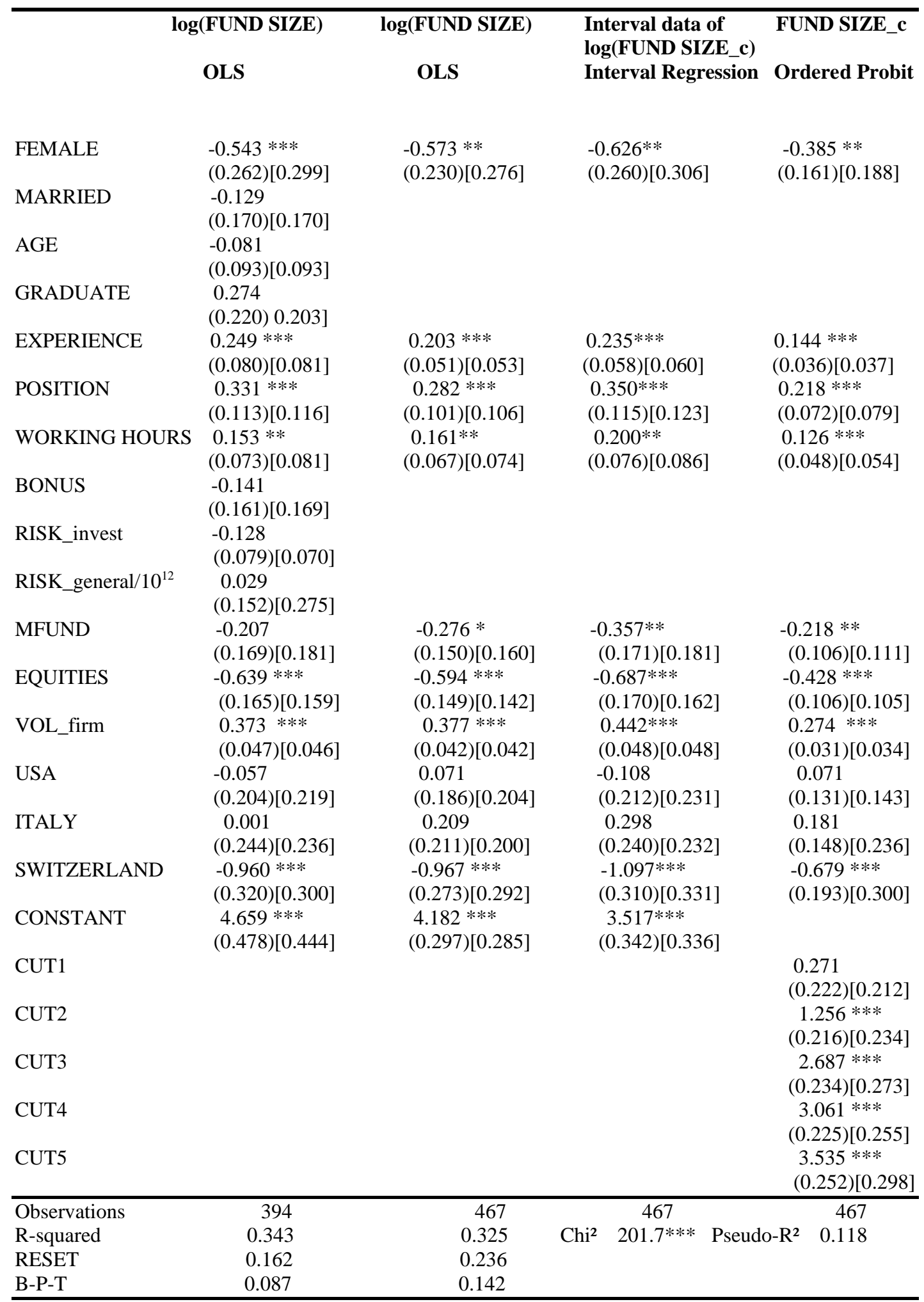

Notes: Standard errors are in parentheses, robust standard errors in brackets. $* * *$ denotes significance at the 0.01 level. ** denotes significance at the 0.05 level. * denotes significance at the 0.10 level based on robust standard errors. In line RESET (regression specification error test) and line B-P-T (Breusch Pagan test for homoscedasticity) p-values are presented. CUT1-CUT5 are unobserved cut-points. 
TABLE 6. Quantile estimates of (log) individual fund size - $\log$ (FUND SIZE)

\begin{tabular}{|c|c|c|c|c|c|}
\hline & 0.90 Quantile & 0.75 Quantile & 0.50 Quantile & 0.25 Quantile & 0.10 Quantile \\
\hline FEMALE & $\begin{array}{l}-0.129 \\
(0.272)\end{array}$ & $\begin{array}{l}-0.052 \\
(0.293)\end{array}$ & $\begin{array}{r}-0.626^{*} \\
(0.335)\end{array}$ & $\begin{array}{c}-0.781^{* *} \\
(0.330)\end{array}$ & $\begin{array}{l}-1.177^{* *} \\
(0.466)\end{array}$ \\
\hline EXPERIENCE & $\begin{array}{l}0.064 * * \\
(0.063)\end{array}$ & $\begin{array}{l}0.151^{* *} \\
(0.064)\end{array}$ & $\begin{array}{c}0.137^{*} \\
(0.076)\end{array}$ & $\begin{array}{l}0.296 * * * \\
(0.085)\end{array}$ & $\begin{array}{l}0.274 * * * \\
(0.101)\end{array}$ \\
\hline POSITION & $\begin{array}{l}0.257^{*} \\
(0.132)\end{array}$ & $\begin{array}{l}0.307 * * \\
(0.125)\end{array}$ & $\begin{array}{c}0.438 * * * \\
(0.147)\end{array}$ & $\begin{array}{l}0.404^{* *} \\
(0.161)\end{array}$ & $\begin{array}{c}0.159 \\
(0.178)\end{array}$ \\
\hline WORKING HOURS & $\begin{array}{l}0.129 \\
(0.093)\end{array}$ & $\begin{array}{c}0.197 * * \\
(0.088)\end{array}$ & $\begin{array}{l}0.202^{* *} \\
(0.097)\end{array}$ & $\begin{array}{l}0.162 \\
(0.101)\end{array}$ & $\begin{array}{c}0.177 \\
(0.142)\end{array}$ \\
\hline MFUND & $\begin{array}{l}-0.296 \\
(0.194)\end{array}$ & $\begin{array}{c}-0.162 \\
(0.189)\end{array}$ & $\begin{array}{l}-0.205 \\
(0.22)\end{array}$ & $\begin{array}{c}-0.404^{*} \\
(0.223)\end{array}$ & $\begin{array}{c}-0.640 * \\
(0.315)\end{array}$ \\
\hline EQUITIES & $\begin{array}{l}-0.437 * * \\
(0.178)\end{array}$ & $\begin{array}{c}-0.667^{* * *} \\
(0.189)\end{array}$ & $\begin{array}{l}-0.643^{* * *} \\
(0.217)\end{array}$ & $\begin{array}{c}-0.727^{* * *} \\
(0.214)\end{array}$ & $\begin{array}{c}-0.426 * \\
(0.250)\end{array}$ \\
\hline VOL_firm & $\begin{array}{l}0.386 * * * \\
(0.053)\end{array}$ & $\begin{array}{l}0.447^{* * *} \\
(0.052)\end{array}$ & $\begin{array}{l}0.390 * * * \\
(0.061)\end{array}$ & $\begin{array}{c}0.350 * * * \\
(0.062)\end{array}$ & $\begin{array}{c}0.305^{* * *} \\
(0.087)\end{array}$ \\
\hline USA & $\begin{array}{l}0.476 * * \\
(0.236)\end{array}$ & $\begin{array}{l}0.429 * \\
(0.243)\end{array}$ & $\begin{array}{l}0.236 \\
(0.272)\end{array}$ & $\begin{array}{c}-0.216 \\
(0.289)\end{array}$ & $\begin{array}{c}-0.841^{* *} \\
(0.369)\end{array}$ \\
\hline ITALY & $\begin{array}{l}0.386 \\
(0.312)\end{array}$ & $\begin{array}{l}0.255 \\
(0.273)\end{array}$ & $\begin{array}{l}0.185 \\
(0.309)\end{array}$ & $\begin{array}{l}0.027 \\
(0.301)\end{array}$ & $\begin{array}{l}0.470 \\
(0.400)\end{array}$ \\
\hline SWITZERLAND & $\begin{array}{l}-0.437 \\
(0.341)\end{array}$ & $\begin{array}{l}-0.394 \\
(0.331)\end{array}$ & $\begin{array}{c}-0.866^{* *} \\
(0.398)\end{array}$ & $\begin{array}{c}-1.158^{* * *} \\
(0.407)\end{array}$ & $\begin{array}{c}-1.561^{* * *} \\
(0.497)\end{array}$ \\
\hline CONSTANT & $\begin{array}{l}6.231^{* * *} \\
(0.288)\end{array}$ & $\begin{array}{l}4.715^{* * * *} \\
(0.352)\end{array}$ & $\begin{array}{c}3.899 * * * \\
(0.427)\end{array}$ & $\begin{array}{l}3.152^{* * *} \\
(0.425)\end{array}$ & $\begin{array}{l}2.852 * * * \\
(0.565)\end{array}$ \\
\hline $\begin{array}{l}\text { Observations } \\
\text { Pseudo R-squared }\end{array}$ & $\begin{array}{l}467 \\
0.171\end{array}$ & 0.232 & 0.247 & 0.202 & 0.119 \\
\hline
\end{tabular}

Notes: *** denotes significance at the 0.01 level. ** denotes significance at the 0.05 level. * denotes significance at the 0.10 level. 
TABLE 7. Quantile estimates of FEMALE coefficients of (log) individual fund size separated by firm size

\begin{tabular}{|c|c|c|}
\hline & VOL_firm $<4$ & VOL_firm $\geq 4$ \\
\hline 0.90 QUANTILE & $-0.169(0.505)$ & $-0.019(0.409)$ \\
\hline 0.75 QUANTILE & $-0.398(0.389)$ & $0.030(0.454)$ \\
\hline 0.50 QUANTILE & $-0.211(0.318)$ & $-0.575(0.483)$ \\
\hline 0.25 QUANTILE & $-0.472(0.496)$ & $-1.598(0.335) * * *$ \\
\hline 0.10 QUANTILE & $-0.325(0.574)$ & $-1.886(0.720) * * *$ \\
\hline Observations: & 214 & 253 \\
\hline
\end{tabular}

TABLE 8. FEMALE coefficients of estimates of (log) individual fund size for subgroups

PANEL A: Subgroup USA vs. other countries

$\begin{array}{cc}\text { USA } & \text { other countries } \\ -0.231 & -0.687 * * * \\ (0.665) & (0.253) \\ {[128]} & {[339]}\end{array}$

PANEL B: Subgroup mutual funds (MFUND) vs. pension funds (PFUND)

$\begin{array}{cc}\text { MFUND } & \text { PFUND } \\ -0.604^{*} & -0.278 \\ (0.329) & (0.562) \\ {[181]} & {[193]}\end{array}$

PANEL C: Subgroup according to seniority of position

$\begin{array}{llll}\text { JUNIOR } & \text { SENIOR } & \text { HEAD of } & \text { CIO/CEO } \\ \text { MANAGER } & \text { MANAGER } & \text { AM team } & \\ 0.128 & -0.768^{* *} & -0.982 & -0.428 \\ (0.451) & (0.324) & (0.769) & (1.382) \\ {[104]} & {[231]} & {[80]} & {[52]}\end{array}$

Notes: *** denotes significance at the 0.01 level. ** denotes significance at the 0.05 level. * denotes significance at the 0.10 level. Standard errors are in parentheses, number of observations in brackets. The same control variables are considered as in Table 5, column (2). 


\section{References}

Albrecht, James W., Anders Björklund and Susan B. Vroman (2003), Is there a Glass Ceiling in Sweden? Journal of Labor Economics, 21, 145-177.

Altonji, Joseph G. and Rebecca M. Blank (1999), Gender and Race in the Labor Market, in: Orley C Ashenfelter and David Card (eds.), Handbook of Labor Economics, Vol.3C, Amsterdam et al.: North-Holland, 3143-3259.

Atkinson, Stanley M., Samantha Boyce Baird and Melissa B. Frye (2003), Do Female Mutual Fund Managers Manage Differently, Journal of Financial Research, 26:1, 1-18.

Arulampalam, Wiji, Alison L. Booth and Mark L. Bryan (2007), Is There a Glass Ceiling Over Europe? Exploring the Gender Pay Gap across the Wages Distribution, Industrial and Labor Relations Review, 60:2, 163-186.

Barber, Brad M. and Terrance Odean (2001), Boys Will Be Boys: Gender, Overconfidence, and Common Stock Investment, Quarterly Journal of Economics, 116:1, 261-292.

Becker, Gary S.(1985), Human Capital, Effort, and the Sexual Division of Labor, Journal of Labor Economics, 3:1, S33-S58.

Bell, Linda, Nina Smith, Valdemar Smith and Mette Verner (2008), Gender Differences in Promotion in Top-management Jobs, Working Papers 08-12, University of Aarhus.

Blau, Francine D., Marianne A. Ferber and Anne E. Winkler (2006), The Economics of Women, Men, and Work, $5^{\text {th }}$ ed., Prentice-Hall.

Boes, Stefan and Rainer Winkelmann (2006), Ordered Response Models, in: Olaf Hübler and Joachim Frohn (eds.), Modern Econometric Analysis, Berlin: Springer, 167-181.

Bonjour, Dorothe and Michael Gerfin (2001), The Unequal Distribution of Unequal Pay - An Empirical Analysis of the Gender Wage Gap in Switzerland, Empirical Economics, 26, 407-427. 
Booth, Alison L. and Jan C. van Ours (2008), Job Satisfaction and Family Happiness: The Part-time Work Puzzle, Economic Journal, 118, F77-F99.

Chevalier, Judith und Glenn Ellison (1999), Career Concerns of Mutual Fund Managers, Quarterly Journal of Economics, 114:2, 389-432.

De la Rica, Sara, Juan J. Dolado and Vanessa Llorens (2008), Ceilings and Floors?: Gender Wage Gaps by Education in Spain, Journal of Population Economics, 21, 751-776.

Dohmen, Thomas and Armin Falk (2006), Performance, Pay and Multi-Dimensional Sorting: Productivity, Preferences and Gender, IZA Discussion Paper No. 2001, Bonn.

Dohmen, Thomas, Armin Falk, David Huffman, Uwe Sunde, Jürgen Schupp, Gert G. Wagner (2009), Individual risk attitudes: Measurement, determinants and behavioral consequences, Journal of the European Economic Association, forthcoming.

Dwyer, Peggy D., James H. Gilkeson and John A. List (2002), Gender Differences in Revealed Risk Taking: Evidence from Mutual Fund Investors, Economics Letters, 76:2, 151-158.

Eckel, Catherine C. and Philip J. Grossman (2008), Sex and Risk: Experimental Evidence, in: Plott, Charles R. and Vernon L. Smith (Eds.), Handbook of Experimental Economics Results, Vol. 1, Amsterdam: North-Holland.

Estes, Ralph and Jinoos Hosseini (1988), The Gender Gap on Wall Street: An Empirical Analysis of Confidence in Investment Decision Making, Journal of Psychology, 122:6, $577-590$.

Frank, Robert H. (1984), Are Workers Paid their Marginal Products?, American Economic Review, 74:4, 549-571.

Gneezy, Uri, Muriel Niederle and Aldo Rustichini (2003), Performance in Competitive Environments: Gender Differences, Quarterly Journal of Economics, 118:3, 1049-1074. 
Green, T. Clifton, Narasimhan Jegadeesh and Yue Tang (2009), Gender and Job Performance: Evidence from Wall Street, Financial Analysts Journal, 65, forthcoming.

Heywood, John S. and Uwe Jirjahn (2002), Payment Schemes and Gender in Germany, Industrial and Labor Relations Review, 56, 44-64.

Hübler, Olaf (2005), Is There a Varying Unexplained Gender Wage Gap in Germany? Applied Economics Quarterly, 51, 29-48.

Juhn, Chinui, Kevin M. and Brooks Pierce (1993), Wage Inequality and the Rise in Returns to Skill, Journal of Political Economy, 101, 410-442.

Madden, Janice (2008), Gender and Stockbroker Compensation: How Complementary Inputs, Selection and Discrimination Affect Performance Pay, mimeo, University of Pennsylvania.

Meng, Xin (2004), Gender Earnings Gap: The Role of Firm Specific Effects, Labour Economics, 11, 555-573.

Menkhoff, Lukas, Ulrich Schmidt and Torsten Brozynsky (2006), The Impact of Experience on Risk Taking, Overconfidence, and Herding of Fund Managers: Complementary Survey Evidence, European Economic Review, 50:7, 1753-1766.

Niederle, Muriel and Lise Vesterlund (2007), Do Women Shy Away from Competition? Do Men Comepete Too Much?, Quarterly Journal of Economics, 122, 1067-1101.

Niessen, Alexandra and Stefan Ruenzi (2007), Sex Matters: Gender Differences in a Professional Setting, SSRN Paper No.966243.

Olsen, Robert A. and Constance M. Cox (2001), The Influence of Gender on the Perception and Response to Investment Risk: The Case of Professional Investors, Journal of Behavioral Finance, 2:1, 29-36.

O’Neill, June E. and Dave M. O’Neill (2005), What Do Wage Differentials Tell Us about Labor Market Discrimination?, NBER Working Paper 11240. 
Schubert, Renate, Martin Brown, Matthias Gysler and Hans Wolfgang Brachinger (1999), Financial Decision-Making: Are Women Really More Risk-Averse? American Economic Review, 89:2, 381-385.

Sirri, Erik R. and Peter Tufano (1998), Costly Search and Mutual Fund Flows, Journal of Finance, 53:5, 1589-1622.

Sunden, Annika E. and Brian J. Surette (1998), Gender Differences in the Allocation of Assets in Retirement Savings Plans, American Economic Review, 88:2, 207-211.

Tversky, Amos and Daniel Kahneman (1992), Advances in Prospect Theory: Cumulative Representation of Uncertainty, Journal of Risk and Uncertainty, 5, 297-323.

Winter-Ebmer, Rudolf and Josef Zweimüller (1997), Unequal Assignment and Unequal Promotion in Job Ladders, Journal of Labor Economics, 15, 43-71.

Wooldridge, Jeffrey M. (2002), Econometric Analysis of Cross Section and Panel Data, Cambridge: MIT Press.

Yellen, Janet (1984), Efficiency Wage Models of Unemployment, American Economic Review, Papers and Proceedings, 74, 200-205. 